IRSH 47 (2002), pp. 2I3-24I DOI: I0.10I7/S00208590020006Is

(C) 2002 Internationaal Instituut voor Sociale Geschiedenis

\title{
Relinking Work and Leisure in Late Victorian and Edwardian England: The Emergence of a Police Subculture
}

\author{
Hai a ShPayer-Makov
}

Summary: Studies of the history of leisure have emphasized the separation between work and leisure which developed with the growth of industrial society. Only scant attention has been devoted by historians and sociologists of leisure to the continuing links between work and leisure throughout the nineteenth century, as reflected in recreational activities organized by employers for their employees. Such attention as has been paid to the subject has concentrated on industrial workers, largely ignoring the more systematic and extensive provision of leisure in work organizations belonging to the public sector. In an attempt to explore linkages between work and leisure in this emerging sector, the article focuses on the English police force and will address the following questions. What did the authorities aim to achieve in imposing control through leisure? How did the policemen react to such policies and was this strategy successful? What prompted the social and economic elite to become involved in moulding entertainment for police employees, and what was the impact of police leisure on the community at large?

Studies of the history of leisure have emphasized the separation between work and leisure which developed with the growth of industrial society. ${ }^{\mathrm{I}}$ Only scant attention has been devoted by historians and sociologists of leisure to the continuing links between work and leisure throughout the nineteenth century, as reflected in recreational activities organized by employers for their employees. Such attention as has been paid to the subject has concentrated on industrial workers, largely ignoring the more systematic and extensive provision of leisure in work organizations belonging to the public sector. ${ }^{2}$

I. For a bibliography of this type of attitude, see Peter Bailey, Leisure and Class in Victorian England (London, 1987), p. 4, n. 3 .

2. For in-depth studies of the links between work and leisure in the mining communities, see Alan Metcalf, "Organized Sport in the Mining Communities of South Northumberland, I $800-$ I889", Victorian Studies, 25 (1982), pp. 469-495; idem, "Football in the Mining Communities of East Northumberland, I882-1914", International Journal of the History of Sport, 5 (1988), pp. 269-291; idem, "Sport and Space: A Case-study of the Growth of Recreational Facilities in East Northumberland, 1850-1914", International Journal of the History of Sport, 7 (1990), pp. $34^{8}-364$. 
In an attempt to explore linkages between work and leisure in this emerging sector, the article focuses on the English police, which, although divided into many forces operating under different authorities, still constituted a loosely unified work organization sharing similar policies. ${ }^{3}$ This occupational group, consisting of over 43,000 employees at the end of the nineteenth century, ${ }^{4}$ serves as a good example of a public institution that combined work and leisure by providing its employees with the means of entertainment at their place of work.

Professional, full-time, uniformed police forces were new phenomena in the nineteenth century, spreading over the English landscape between I 829 and the late i $850 \mathrm{~s}$. In the process of formulating employment strategies, police authorities in different parts of the country increasingly incorporated the provision of leisure as an integral part of the conditions of police employment, particularly in the large forces.' Policemen became both spectators and participants in work-related recreation. London's Metropolitan Police, by far the largest of all police forces in the country and located in the national centre of pleasure-seeking pursuits, excelled in their exertions in this direction. Many other police forces, though they could not afford to be as active and as generous as the police in the metropolitan area, nonetheless followed a similar pattern and organized diverse recreational facilities for their employees. In fact, the police stood out among employers both in terms of the scope of leisure provided and the scale of involvement of both management and employees. The police became a pioneer of various modern recreational activities, and can be counted among the forces that entrenched "the basic pattern of contemporary sport". 6 As a result, a multifaceted and vibrant police culture was created, enjoyed not only by police employees but often by the general public.

The article proposes to describe this leisure culture and analyse the factors that underlay its rise and expansion. Such an account will shed light on an institution that played an important role in the development of leisure in England but has hitherto been ignored by historians of leisure; and on the motives of people who were not associated with the world of leisure but had a strong impact on its evolution.

Arguably, recreation in the police was provided partly as a means of escape from the strictly enforced work routine and as compensation for the harsh conditions of service. The contention of this article, however, is that over and above any other motive, after-work culture was the product of

3. Most findings in this article relate to the English and Welsh police.

4. Police Review, I० May 1901, p. 2 I8.

5. For an article on the policeman as a worker in a broader European context, see Clive Emsley,

"The Policeman as Worker: A Comparative Survey, c. I800-1940", International Review of Social History, 45 (2000), pp. 89-1 10.

6. Richard Holt, Sport and the British (Oxford, I989), p. 9. 
the interest of police management in developing strategies of employee control. In common with other employers who provided their employees with recreational facilities, the principal objectives of the police authorities were to maximize efficiency and supervise their workers. ${ }^{7}$ As a new work organization redolent with disciplinary problems, the police searched for effective methods of control, especially against the background of dramatic changes in the labour market at large and the resultant crisis of authority in the world of work. The underlying assumption was that control should be exercised both during and after work. The provision of leisure was meant to attain both and was adopted as a policy when it became clear that other means were insufficient. Ironically, the ordinary policeman, resented by his social peers for epitomizing the growing intervention of the state in the daily life of the working classes, was himself the object of supervision and control, even in his spare time. ${ }^{8}$ In contrast to the majority of workers in the country, he was not free to disengage himself from his employer once his work-day was over.

In order to understand the continuing links between work and leisure, an examination of this system of control is essential and will address the following questions. What did the authorities aim to achieve in imposing control through leisure? How did policemen react to policies which ostensibly provided them with amusement after work but in practice were meant to curtail their freedom of choice? Was this strategy successful, and were management's objectives fulfilled? What prompted certain sectors of English society to become involved in moulding entertainment for police employees, and what was the impact of police leisure on the community at large? This inquiry into the motives and policies of the police authorities and into the officers' experiences of police leisure will illuminate new aspects of labour history and the development of patterns of cultural consumption during the late Victorian and Edwardian periods.

\section{CONTROL AFTER WORK}

Despite the prevalent rhetoric of laissez-faire in Victorian England, many employers retained an older conviction that the free time of workers was not their own to do with as they pleased. Furthermore, they perceived the worker as in need of guidance and supervision even in his spare time. If he was to be an efficient worker, he was not to do what he wanted, whether during work or afterwards. This type of reasoning characterized the police from the very beginning. Police authorities firmly believed that too much

7. For other such employers, see Bailey, Leisure and Class in Victorian England, pp. 62-63.

8. Ibid., pp. 33-35; Robert D. Storch, "The Policeman as Domestic Missionary: Urban Discipline and Popular Culture in Northern England, I 850-1880”, Journal of Social History, 9 (1976), pp. 48 I -509. 
free time away from the observant gaze of superior officers actually harmed police work.

An experiment conducted by Edmund Henderson, Commissioner of the Metropolitan Police between I 869 and I 886, seemed to him to confirm this long-held assumption. No Sunday leave existed in the force prior to I869. As soon as Henderson became Commissioner, he granted the Metropolitan Police one day's leave in seven, although not necessarily on Sundays. Two years later, however, he reversed his decision and would allow no more than two days' leave a month, only one of which was to be a Sunday. He explained that contrary to expectations, the experiment "has not increased the alertness or efficiency of the police", while he had "too much reason to believe that, especially among the younger constables, the day off duty is spent in a manner that detracts from instead of increasing their efficiency". Attempts to change this policy over the next few decades failed, even though some of them emanated from the Archbishop of Canterbury and the Bishop of London, who were anxious to give policemen appropriate opportunities for divine worship. ${ }^{\circ}{ }^{\circ}$ In the event, Metropolitan policemen continued to have only two days' leave a month until the implementation of the Police Weekly Rest-Day Act of r9ro on the eve of the First World War. This situation was replicated in most borough forces, except for places such as Leeds, which gave only one day off a month, and Colchester, which allowed only one day off per quarter. ${ }^{\text {II }}$ There were policemen who worked in the police for eight or nine years without a Christmas leave. ${ }^{12}$ Further, not only were policemen throughout this period deprived of a weekly rest-day (which was enjoyed by most workers in the country), and sometimes of Christmas leave, but in common with many other workers in the public sector, they were not trusted to do as they wished during the time not allocated to work. ${ }^{13}$

Control exerted after work-hours took many forms. Not only did officers endure long working days and weeks, but they were liable to be called back to duty at any time of day or night with no additional pay. ${ }^{\mathrm{I}}$

9. "Memorandum by the Commissioner of Police", i I April I 870, in Select Committee on the Police Forces (Weekly Rest-Day), PP, I908, vol. 9, p. 687.

Io. Ibid., p. 688.

I I. Even after the passage of the Act, constables and sergeants were given one day of rest only every fortnight in places such as Hertfordshire; Police Review, 24 January 191 3, p. 43. Some forces did, however, have paid annual leave, e.g., ten days in the London, Leeds, and Colchester forces at the turn of the century.

I2. Ibid., i 8 December I 893, p. 610.

I3. "The Policeman's Diary", All the Year Round, 5 January i 889, p. I0.

I4. "Return of all General Orders, Issued by the Magistrates appointed under the Act of I 829 , since the formation of the New Police”, I June I830, PP, I830, vol. 23, p. 410; Select Committee on Police Superannuation Funds, PP, I875, vol. I3, p. 479. 
The implication was that they were paid not for a certain amount of hours per day or week but that their labour power was to be given whenever necessary. As was stated in the first set of police orders of the Metropolitan Police in I 830 and reiterated thereafter: The constable "will devote the whole of his time and abilities to the service". Is

This strategy of control was also manifested in the residential policies of the police. The rule in the Metropolitan Police dictated that married officers must live near the station and single officers in the section house, an establishment usually adjoining the main station of each division. The idea was to have the men within easy reach both in the event that they were needed in an emergency and in order to be under the close supervision of superior officers at all times. ${ }^{16}$ In the same vein, officers outside London were required to reside either in police accommodation or in their own habitation which must be close to their workplace. Control over the residential arrangements of officers thus served police purposes both in terms of the flexibility of labour power and the ability to scrutinize officers when not on the beat.

In order to entrench a positive reputation for the new police forces and demonstrate to the public that the police had the moral authority to impose restrictions on the citizenry, the officer was expected to exemplify model conduct and good character even after work. Police orders required him to exhibit "a perfect command of temper, never suffering himself to be moved in the slightest degree by any language or threats that may be used". ${ }^{17}$ Self-control and good manners, he was taught, would help him in the performance of his duties, since such conduct "will probably induce well disposed bystanders to assist him should he require it". Drinking alcoholic beverages on and even off duty was forbidden, as was talking to local maids.

In the belief that policemen should have a morally sound family relationship, superior officers regularly intervened in the choice of a bride, and once the choice was made and the couple was married, wives were expected to behave according to the moral imperatives of respectability. ${ }^{18}$ Wives who misbehaved could jeopardize their husbands' status and chances of promotion. During the first few decades after the founding of the police, even the officers' appearance after work was exposed to strict regulation. Beards and moustaches were forbidden in the Metropolitan Police, as well as in other forces, and policemen were obliged to wear their

I 5. "Return of all General Orders", i June I830, PP, I830, vol. 23, p. 4 I4.

16. Ibid., p. 4 10; Wilbur R. Miller, Cops and Bobbies (Chicago [etc.], 1977), pp. 22-23; Carolyn Steedman, Policing the Victorian Community (London, I984), p. I I9.

17. "Return of all General Orders", I June I830, PP, I830, vol. 23, p. 4I5.

18. Police Review, 25 July i900, p. 35 I. 
uniform outside work. ${ }^{19}$ Moreover, attendance at church was required in many forces. ${ }^{20}$

With time, the authorities relaxed some of the rules, in particular those relating to the officers' appearance, such as the need to wear a uniform outside work and the ban on beards and moustaches. ${ }^{21}$ While policemen were still urged to be accessible off-duty, reside near work, and lead a respectable lifestyle, control in the last third of the century gradually shifted from coercive to subtler means. In their search for ever more effective means of disciplining employees without losing them to other employers, the authorities maintained a harsh regimen, but at the same time adopted new means of persuasion through positive incentives. Developments in society at large prompted this trend. The democratization of the political process and of public life, and greater attention to the rights of labour in the country fostered more accommodating solutions. The expansion of working-class leisure in the country during the I870s was another important influence. ${ }^{22}$ Within the parameters of a traditionally tight-fisted compensation policy, police decision makers nonetheless introduced pay rises, extended the welfare package, and initiated other bonuses which ameliorated the life of the policemen. Additionally, an ever-widening range of recreational activities was instituted in police stations, section houses and other locations - part of a strategy of subordination by new means.

Reading rooms and libraries had existed in some forces prior to the late I86os, but little else had been offered to policemen by way of entertainment. ${ }^{23}$ Starting around that time, reflecting a policy of reinforcing police conformity and loyalty by offering inducements while still preserving tight control, recreational activities became an integral component of the employment structure of the English police. Police authorities in various parts of the country began making concerted efforts to develop an infrastructure for a pleasurable system of recreations to be enjoyed by employees after work hours. Implicit in this recreational system was a combination of old and new concepts of labour control. While the working day and leisure time were demarcated, the police

19. "Return of all General Orders", I June I830, PP, I830, vol. 23, p. 409; Steedman, Policing the Victorian Community, p. I 19.

20. Ronald C. Sopenoff, "The Police of London: The Early History of the Metropolitan Police, I 829-1 8 56", Ph.D. thesis, Temple University, 1977, pp. I72, I87-1 88, 203; A.A. Clarke, Country Coppers: The Story of the Policemen of the East Riding, 1857-1968 (Hornsea, 1993), p. 28: Douglas J. Elliott, Policing Shropshire I836-1967 (Studley, I984), pp. 69, I I9; John Woodgate, The Essex Police (Lavenham, 1985), pp. I4-I5; Steedman, Policing the Victorian Community, p. I 20.

21. Report of the Commissioner of the Police of the Metropolis for the year I869, PP, I870, vol. 36, p. 497.

22. Bailey, Leisure and Class in Victorian England, p. 91.

23. A. Wynter, "The Police and the Thieves", Quarterly Review, 99 (I856), p. I7I. 
authorities integrated work and leisure by initiating nonwork activities in the workplace, and by the close control by superiors of the leisure of their employees. Work became a site for pleasure, while for single men living in the section house, work, home, and leisure were intimately linked. Interestingly, the official who was instrumental in introducing leisure amenities into the section houses in London and widening the recreational facilities offered to policemen in the capital was none other than Edmund Henderson, the same Commissioner of the Metropolitan Police who had limited the free time available to policemen. On closer look, his initiative in the sphere of recreation was the logical outcome of his basic assumption that officers should not be left unmanaged.

\section{FORMS OF POLICE LEISURE}

In order to attain hegemonic power over their labour force, the officials in positions of command in the police hierarchy felt that first and foremost officers must be insulated from unedifying environments and their social milieu overseen. ${ }^{24}$ The aim was to lure the officers away from immoral influences, whether they lived in police quarters or not, during work and after. As part of this protective strategy, policemen were asked to give up the most popular entertainments of the English working classes, to which most of them belonged, and adopt the values preached by their superiors. They were warned to exercise "self-denial", and "to beware of the pothouse", and never to set foot "over the threshold of a public-house unless in the proper discharge of their duty". ${ }^{25}$ Gambling, too, was forbidden.

Barring officers from certain pleasures was not, however, enough to induce submission and conformity. At a time when working people increasingly took advantage of expanding entertainment choices, the authorities could not merely distance officers from popular pastimes, but had to provide alternative leisure. Unlike the traditional paternalist employers, the heads of police fixed the parameters for the leisure of their employees and decided on the types of recreation to be made available. These amenities were not chosen at random. From the late i 860 s onward, senior officials carefully planned a programme of entertainments that would fill management's needs, and an array of leisure facilities was gradually introduced in police stations and section houses. In addition to reading rooms and libraries, recreation rooms were set up and furnished with chess, draughts, billiard tables, bagatelle boards, cards, and dominoes

24. E.g., Report of the Commissioner of the Police of the Metropolis for the year 1869, PP, I870, vol. 36, p. 497; Report of the Commissioner of the Police of the Metropolis for the year 1870, PP, I 87 I, vol. 28, pp. 595, 605, 609, 6I ; Report of the Commissioner of the Police of the Metropolis for the year I87I, PP, I872, vol. 30, p. 3 I 4 .

25. Police Guardian (formerly the Police Service Advertiser), s March I875, p. 4. 
to cater for the men's need for relaxation after they ended their shifts. Men with musical talents could participate in bands and choral societies formed by some of the forces or divisions. Appearing in uniform, the bands performed in police fêtes and galas and in outdoor venues for the public at large. Some men formed glee clubs.

Officers were also provided with entertainment outside the stations. Beginning in the early i 870 , first in London and the southern and midland counties and then in the north, annual balls and New-Year festivities with dinner and dancing became an integral part of the officers' calendars. This novelty was appreciated by constables and superior officers alike. All officers began to "cast off official restraint, and to meet together [...] for mutual intercourse and social enjoyment", in the words of a superintendent in Manchester who saw these balls as "a new phase in the social life of the police force of this city". ${ }^{26}$ Outdoor social events such as picnics and excursions were other newly emergent traditions. ${ }^{27}$

During the same period - the late I 860 s and the I 870 - athletic pursuits began to assume an ever-growing significance in police culture. Team games, starting with cricket and moving on to football, were promoted. Other sports were soon added, including boxing, wrestling, quoits, cycling, rowing, and water polo. Developments in the world of leisure outside the police constantly impacted on the police. Increasingly, sports activities became more codified, organized, and institutionalized in clubs, first in London and then in the provincial forces. ${ }^{28}$ Cricket, rowing, and swimming clubs were formed under the patronage of top police officers. Football, cycling, and quoiting clubs soon followed. Against the background of the Boer War, clubs for miniature rifle shooting opened in different parts of the country. London alone had i7 such clubs, with a membership of $2,000 .{ }^{29}$

Tournaments, races, and competitions were encouraged in each type of sport. These included ball-game matches, swimming and rowing competitions, matches in miniature rifle shooting, billiard handicaps, running and jumping competitions and tug-of-war races. Leagues were organized, and matches between stations, divisions, forces, and clubs, as well as against nonpolice teams, became widespread. Encouraging "sport as far as they possibly could", top officials designed cup competitions in a variety of sports, further systematizing this brand of activity..$^{30}$

Full day events were organized for officers' families as well as local inhabitants. Such events involved an array of activities for every taste. The

26. Ibid., 23 February, I872, p. 5.

27. Other occupational groups, such as miners, initiated similar patterns at this time. See Metcalf, "Organized Sport in the Mining Communities of South Northumberland", p. 478.

28. Select Committee on Police Superannuation Funds, PP, i877, vol. I s, pp. I46-I 47.

29. Police Review, I 8 October I912, p. 498.

30. Ibid., I9 February 1909, p. 87. 
annual police fête day in aid of the Metropolitan and City Police Orphanage featured high jumps, hurdle races, bicycle handicaps, and polo matches, along with singalongs, a balloon ascent, and a performance by the police minstrels. ${ }^{3 \text { I }}$ Thirteen police bands played throughout the day, ending with "a grand display of fireworks". So integral did the attendance at or participation in sports activities become, that some police authorities, while denying officers permission to attend prayer services on Sunday, would grant such permission in the case of sport. ${ }^{32}$ Apparently, sports and other amusements were gradually replacing religious ceremonies as a means of control.

Not all officers were presented with the same opportunities to enjoy themselves. Large forces were better able to initiate a variety of activities. They could afford the manpower to organize them and the free time for players to practice and perform. Officers in these forces were privileged in this respect. One officer from a county force in Staffordshire complained in a letter to the Police Review, a journal of officers' opinions, that "the majority of us in this County have not any facilities for taking part in any sports or other social games". 33 Whatever the ability of individual forces, they were impelled by similar considerations.

\section{RECREATION AS AN EMPLOYER STRATEGY}

Clearly, some police officials were interested in enlivening the work atmosphere of officers and wanted them to have some enjoyment. ${ }^{34}$ Related to this was the urge to compensate them for harsh employment conditions and create a more satisfying work environment. ${ }^{35}$ This newer sensitivity to the needs of ordinary policemen can be detected in the discourse of authority figures who, from the late i 860 s increasingly emphasized their "deep interest" in all that concerned the officers' "wellbeing and happiness". ${ }^{6}$ "The officials acknowledged more readily that the daily life of policemen was "almost the direct contrary to that of their neighbours", particularly due to long work hours and the shift system which obliged them to work nights. Since police officers worked on most Sundays as well, they had "no one to make holiday with them; their children are engaged in some way; their friends are all engaged in business", as a former police surgeon emphatically pointed out. ${ }^{37}$ This

31. Ibid., 3 I July i 900 , p. 33 I.

32. Ibid., 25 May I 894, p. 243.

33. Ibid., I9 October 1900, p. 495 .

34. Select Committee on the Police Forces (Weekly Rest-Day), PP, I908, vol. 9, p. 706; Police Review, I6 September 1910, p. 444.

35. Police Guardian, 22 January i 875 , p. 4.

36. Police Service Advertiser, 23 February I872, p. 5; Police Guardian, 5 February I875, p. 3.

37. Select Committee on the Police Forces (Weekly Rest-Day), PP, i908, vol. 9, p. 730. 
system disrupted "domestic sociality", a Manchester police inspector observed, noting that police soirées and balls kept alive in officers "the fact that sociality with one another was one of the chief characteristics of the human race". ${ }^{38}$ In the same vein, a superintendent in the Manchester force admitted that the policeman "is precluded from participation in much that Englishmen prize as the inheritance of their birth-right; and if he is a sensitive man, that isolation and seclusion presses on him all the more heavily". ${ }^{39} \mathrm{He}$ added tellingly: "There was a time when to have suggested such a thing would have been considered a foolish absurdity; but happily that time is gone by".

Increasingly, the rhetoric of senior officers explicitly reflected the intention to make police life easier for officers. Referring to arrangements in a new section house built in I 886 especially for trainees in London, one of the superintendents explained that "everything has been done to promote the comfort and happiness of the residents". $4^{\circ}$ Contented policemen, it was now believed, made better employees. The sense of gratification engendered by recreation was meant to serve as a measure of compensation not only for long hours of work but also for the physical and mental exertion and the perpetual exposure to inclement weather which continued to characterize police work even at the turn of the century. As time wore on, attention to the officers' feelings was more pronounced. Commissioner of the Metropolitan Police, Edward Henry (1903-1918), reflected this sensitivity when he acknowledged the benefit for policemen of taking their leave "away from their existing surroundings". ${ }^{\mathrm{I}}$ While police recreation still served as a means of control (and Henry objected still to a weekly day of rest), he believed that some "change of surroundings", for instance during the officers' annual holiday, could make the leave "a health-giving and really beneficial rest". ${ }^{42}$ In contrast to Henderson, more and more senior officers felt it important to declare: "If you have respectable men in the force you must trust them. You do not want to have anybody looking after them when they are on their day's leave. They are like the workman when he gets his day off." 43 By then, Henderson's patronising rhetoric of earlier decades was no longer acceptable. Control was still exercised over the men's free time, but in ever subtler ways, while rhetoric tried to camouflage this control.

Indeed, the discourse of those in power suggests that above all they aimed at using work-related leisure to meet the demands of management.

\footnotetext{
38. Police Service Advertiser, 23 February i872, p. 5.

39. Ibid.

40. Report of the Commissioner of the Police of the Metropolis for the year I885, PP, I886, vol. 34, I 886, p. 366.

4I. Select Committee on the Police Forces (Weekly Rest-Day), PP, 1908, vol. 9, p. 700.

42. Ibid.

43. See evidence of Captain Henderson, Chief Constable of Reading, in ibid., p. 725 .
} 
The main impetus was pragmatic rather than humanistic. Commissioner Henry, too, in supporting a holiday away from the police environment, was motivated by the benefit that would accrue to police work. He was convinced that after a break, officers would "return braced up in mind and body, and capable of rendering more efficient service". ${ }^{44}$ This pragmatic attitude perpetuated paternalistic policies. The employment strategy followed by police heads all over the country was to construct a workforce that was physically strong, stable, committed, and acceptable to the public. In this context, the linkage of work and leisure in the police forces reflected the perception that most recreational activities had the potential to enhance police skills. This perception dictated the type of leisure to be pursued by the police.

Accordingly, the common denominator of all police entertainments was their association with what at the time was called "rational recreation", a term used by middle-class reformers to denote healthy, mind-improving, and orderly recreations. Intrinsic to police ideology was the conviction that policemen needed to project a respectable image, whether in uniform or not, and to internalize the values associated with an edifying way of life. The adoption of "rational recreations" served these purposes. Unlike the premodern link between work and leisure, the police authorities laid emphasis on the respectability of the amusements pursued by policemen. Assimilating the middle-class critique of traditional plebeian culture, they avoided any offence to the social order, and dispensed with violent, bawdy, or unruly amusements, which in the past were an integral part of workingclass leisure. Social evenings and day events involved eating and drinking, but lacked the carnavalesque atmosphere typical of the lower classes of olden times. Even mass occasions were orderly events. The guiding principle was that "whatever tends to elevate the moral tone of the young constable is a decided gain to the public".45 Internally, the choice of recreational activities and the supervision of them by superior officers ensured that ordinary policemen pursued respectable pastimes and engaged in "clean and healthy sport" which strengthened desirable work habits. ${ }^{46}$

Physical recreation fell into this category, especially as establishment opinion in the country was increasingly prone to include it amongst respectable leisure activities and attribute to it a civilizing influence. ${ }^{47}$ Additionally, since physical dexterity was deemed essential to the efficient performance of police duties, only recruits in an above-average state of health with impressive physical attributes were accepted into police

44. Ibid., p. 700.

45. Report of the Commissioner of the Police of the Metropolis for the year I885, PP, I886, vol.

34, p. 366.

46. Police Review, i6 September i910, p. 444.

47. Police Service Advertiser, 30 August I872, p. 3 . 
service. In the belief that the use of a gymnasium "would be beneficial to the physical welfare" of the men, police authorities all over the country combined expediency with pleasure-giving by embarking on a strategy that enhanced the physical skills of their employees. $4^{8}$ Engaging in athletics was meant to enable the officers "to deal with disorderly men, and hold their own against odds, as they were often called upon to do".49 Not only was sport healthy, it "made the men fitter for their arduous duties in the street".50 Swimming, too, was considered a "useful art", particularly for members of the Thames Police which relied on men with maritime skills to do the job of preventing crime on the river proper. ${ }^{S \mathrm{I}}$ Accordingly, police swimming and rowing clubs were instituted in various cities. The athletic club of the City of London Police sponsored boat races. Contributing to the development of expertise specific to the police, the swimming clubs trained the men to save lives along with providing facilities for recreational swimming. ${ }^{2}$ In some forces, instructors of gymnastic exercises or wrestling trained officers with the intention of improving their combat skills. Such activities were expected to yield concrete results. Indeed, senior officers assiduously highlighted cases such as that of Constable Watt, well known as an athlete, who rescued a man from a burning room in Chelsea. For them, this was yet another demonstration that "a good athlete was invariably a good policeman". 53 Such evidence of the beneficial effects of participation in sports activities on police performance propelled the authorities to continue expanding the system of leisure. A driving force in increasing the number of cycling clubs in the Lancashire Police, for example, was the "useful service rendered by several Police on bicycles" during the coal strike of I 893.54

Ordinary policemen shared this belief in the value of sports for the better functioning of the police. Football, one officer argued, "would keep the men in splendid order" and make them "more capable of successfully running down a run away thief". ss Others thought that wrestling was "very useful to the men as policemen", for "they never knew what they might be called upon to do in performing their duty". ${ }^{6}$ Such an attitude allowed them both to enjoy themselves and to feel that sports enhanced their occupational skills.

Police leisure, however, was expected to do more than enhance the

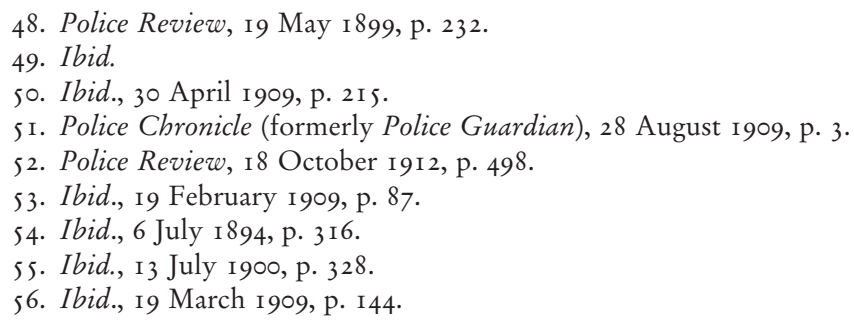


physical capability of the men. It was also meant to ensure that the principles underlying the employment structure were reinforced, i.e. that the officers' behaviour would meet the demands of management for stability, discipline, and commitment. Leisure amenities were provided to build up "character" and reaffirm the behaviour and attitudes appropriate to the ideal policeman as defined by police leadership.

One of the problems that plagued the police and undermined their efficiency was high turnover. ${ }^{57}$ The harsh daily routine and strict discipline rendered police work unattractive and prompted many officers to leave prematurely. Of those that remained, many became alienated from their place of work. ${ }^{8}$ Creating a rewarding work environment through the provision of leisure was a way of tying the officers to their workplace and reducing the excessive rate of voluntary departure. Moreover, while, on the whole, nineteenth-century England did not suffer from a shortage of labour, the police forces were highly selective in their hiring policies, demanding physical characteristics well above those of the ordinary workingman and therefore experiencing large numbers of vacancies until the 1880 os. 59 The police authorities hoped that highly developed leisure would help attract suitable candidates and convince them to overlook the unsavoury side of police work. Colonel James Fraser, Commissioner of the City of London Police between I 862 and I 890, believed that

[...] many respectable men are deterred from entering the Police Service, because they labour under the impression that the life of a constable is one monotonous round of unpleasant duties, without a break for enjoyment and amusement, and it is probably owing to this impression, and the recent low rate of wages, combined with other causes, that there has been so much difficulty in keeping up the strength of most large forces. ${ }^{60}$

He was convinced that police recreation "will go far to show the public that a policeman's life, in modern times, can be smoothed and his path made pleasanter, even should he be confined to the dreariest beats of our largest cities". This impression, he firmly believed, would induce officers

57. Select Committee of the Police Superannuation Funds, PP, 1875, vol. I3, pp. 434, 482, 575; Steedman, Policing the Victorian Community, pp. 92-96, I6r; Haia Shpayer-Makov, "The Making of a Police Labour Force”, Journal of Social History, 24 (1990), pp. I09-I I I.

58. Select Committee on Police Superannuation Funds, PP, I875, vol. I3, pp. 577-578.

59. Report of the Inspector of Constabulary and Police Forces: Eastern Counties, Midland, and North Wales District, PP, I 871, vol. 28, p. 349; Report of the Inspector of Constabulary and Police Forces: South of England and South Wales District, PP, 1874, vol. 28, p. 278; Report of the Inspector of Constabulary and Police Forces: Northern District, PP, 1875, vol. 36, p. I I6; Report of the Inspector of Constabulary and Police Forces: Eastern Counties, Midland, and North Wales District, PP, 1876, vol. 34, p. 6; Select Committee on Police Superannuation Funds, PP, 1875, vol. I3, pp. 4I 2, 426, 44I.

60. Police Guardian, 23 February i875, p. I. 
to stay in service and have the effect of stabilizing the force. His view was shared by many police officials. ${ }^{6}$

Another essential requirement of police management was a pliant employee. In common with other public institutions, rigid discipline and the strict regulation of conduct typified police organizations. Leisure was considered a tool of control, not only because it rendered officers more appreciative of management but also because of the contemporary belief in the link between systematic physical exercise and discipline and order. ${ }^{62}$ The very engagement in organized and codified games would make participants obey rules and regulations more readily and punctually. ${ }^{63}$ In addition, whether in the section house or while pursuing some sport, the men could "be immediately brought under discipline". ${ }^{64}$ In the very act of playing, exercising, and competing were constructive attributes that institutions could exploit. That these values were thought to promote bourgeois ideals of self-reliance, self-restraint, industriousness, obedience to rules, and maximum effort made investment in leisure even more cogent to police administrators.

Clearly, the police policy makers used the system of leisure to reinforce the authority structure embedded in the forces. The attendance of senior officers at races, competitions, and performances by the men and at gala events, was yet another method of control used by the authorities to acclimitize policemen to police culture and to the moral imperatives advocated by respectable opinion. The presence of the police leadership stamped these occasions with authority. Contrary to the practice of local notables and employers in pre-industrial society, but in conformity with the new paternalism unfolding in the world of work during the nineteenth century, police management did not usually participate in the recreational activities alongside their employees, but stood at a distance as spectators. It took no effort to differentiate between their respective positions in the police hierarchy. The fact that they, or their wives, presented the winners with prizes, medals, and trophies, often using the opportunity to preach consensual values, highlighted the power structure in the police and put management attitudes on display. In turn, the authorities would enjoy a vote of thanks and cheers from the rank and file. ${ }^{65}$

Another important aspect of police recreations was the notion that they "were means to bring Officers and men and friends together", thereby

6r. Select Committee on Police Superannuation Funds, PP, I877, vol. I 5, p. I46.

62. Keith A.P. Sandiford, "Cricket and the Victorian Society", Journal of Social History, i7 (1983), p. 3 10.

63. Police Service Advertiser, 30 August I872, p. 3.

64. Report of the Commissioner of the Police of the Metropolis for the year I885, PP, I886, vol. 34, p. 366.

65. E.g., Police Review, 2 I December 1900, p. 607. 
promoting solidarity. ${ }^{66}$ "While this unity existed", the Police Review asserted, "the public benefited". In the opinion of Colonel Fraser, who was one of the first administrators "to recognise the value of a few nights' recreation, interspersed throughout the duties of the year", police festivities "tend in the highest degree to foster a 'corps d'esprit', which might under other circumstances perhaps be found wanting". ${ }^{67}$ Recreation rooms offered an outlet for individual pursuits, although greater emphasis was laid on group sports, on playing and winning for the team and on togetherness. Social evenings, too, were often organized around team games. Additionally, delegates to meetings and conferences of self-help police institutions, such as the Police Mutual Assurance Association and the International Christian Police Association, were entertained at special dinners and outings attended by large numbers of guests.

Yet another reason for the support by superior officers for sports activities among the men was because it provided them with entertainment and filled their own leisure needs. The upper strata of the police in each locality attended games and matches in full force, taking pride in the high standards of sport that were attained. An additional bonus was the lunches or dinners with "exceptionally good" catering which followed some of these events. ${ }^{68}$ So keen were superior officers on promoting the quality of police sport teams that they were willing to bend admission requirements and accept recruits "a year or two under age ostensibly for the purpose of playing cricket, and every possible favour and facility [was] granted them to ensure personal success". ${ }^{69}$ After the season was over, the athletes were given "some expensive present out of the funds to the disparagement of men who have been in the Force 12 to 20 years". ${ }^{\circ}$ The better the achievements of the team, the greater the satisfaction and prestige of the senior officers who promoted it.

No less important was the fact that police recreation involved only limited expense to the authorities. A large proportion of the costs was borne by the men themselves, either by compulsion or voluntarily. ${ }^{71}$ Policemen in the Metropolitan Police were required to pay half a penny a week for the police bands and libraries. This sum, and the money earned from performances, must have more than covered the costs of the bands. The receiver for the Metropolitan Police, A.R. Pennefather, confidently declared in 1908 that the police authorities did not pay "a farthing" for the bands..$^{72}$ Policemen paid for their own instruments. Choirs and bands

66. Ibid., I9 March 1909, p. I44.

67. Police Service Advertiser, 23 February i 872, p. I.

68. Police Review, 4 September 1893, p. 423.

69. Ibid.

70. Ibid.

71. Ibid., 25 May I894, p. 244.

72. Select Committee on the Police Forces (Weekly Rest-Day), PP, I908, vol. 9, p. 717. 
brought in ticket proceeds. Profits were used to purchase equipment and improve the facilities in recreational rooms. ${ }^{73}$ Police sports clubs were financed by the monthly subscriptions of members. Some of the money made by the bands went to police charities, particularly the orphanages.

In addition to contributing their own share of the costs of various events by personal donations, policemen made efforts to get subscriptions from the public in order to finance activities. When Edward Bradford, Commissioner of the Metropolitan Police between I890 and I903, temporarily banned such a practice, decreeing that sports clubs should be "entirely self-supporting", he evoked the consternation of the rankand-file, as this could have ended the existence of many of the clubs. ${ }^{74}$ Constables in various forces were often instructed by their superior officers to collect money from local ratepayers, publicans, and residents on their beats. Significantly, police entertainments were consistently supported by philanthropists and wealthy patrons who viewed such support as being in their own interests (see below).

Promoting the standing of their employees in the community was high on the list of police priorities - an aspiration shared by few other employers. Opposition to the establishment of organized and professional police had been widespread when the idea was raised in the late eighteenth and early nineteenth centuries, and continued long after the police were a firm reality. ${ }^{75}$ Police recreations were designed, inter alia, to eradicate this opposition and elicit support for the police. Sporting matches were perceived as doing "much to cement the good feeling existing between the Police and public, and this good influence filtered through to the lowest ranks of the Force". ${ }^{76}$ Indeed, police spectator sports all over the country provided public entertainment and attracted large crowds. ${ }^{77}$ Some concerts were so popular that many could not gain admission..$^{78}$ In 1905 alone, upwards of 2,300 men attended the Sunday afternoon special events and social evenings organized by the International Christian Police Association in London for police candidates. ${ }^{79}$ Annual events, such as the Metropolitan and City Police fête, could draw thousands of fee-paying

73. William McAdoo, "The London Police from a New York Point of View", Century Magazine, 78 (1909), p. 659; Police Review, 21 December 1900, p. 607.

74. Police Review, 5 April i 895 , p. 160.

75. On the reasons for the opposition to the formation of modern police forces, see Miller, Cops and Bobbies, pp. I2-14, 104-106.

76. Police Review, 30 April I909, p. 21 s.

77. See, e.g., Report of the Commissioner of the Police of the Metropolis for the year I870, PP, I871, vol. 28, p. 595; Police Service Advertiser, 30 August I872, p. 3; Police Review, 20 July 1906, p. 344 .

78. Report of the Commissioner of the Police of the Metropolis for the year $1871, \mathrm{PP}, 1872$, vol. 30, p. 3I4.

79. Police Review, 4 May I906, p. 207. 
spectators. Despite poor weather conditions, about 80,000 visitors came to this event in $1910 .{ }^{80}$

Police recreations appealed to a wide spectrum of audiences. Not only did members of the public enjoy police performances, wrestling displays, gymnastic and other sport spectacles, but some of the needy benefited from police charitable performances. At the suggestion of senior officers, police bands performed in outdoor venues "for the benefit and amusement of the poor, without receiving payment of any kind for their services" ${ }^{8}{ }^{1}$ Such concerts were organized in order to obtain money to buy necessities for the poor, such as clogs and stockings. ${ }^{82}$ At the other end of the social spectrum, the Police Minstrels Troupe was one of the principal attractions at a birthday party given in 1909 for Prince Henry of Wales. ${ }^{83}$ Thus, the introduction of recreational facilities and festive events into police culture affected not only the policemen's lives but the broader social milieu as well.

Although not all police officials viewed work-related leisure as productive - some objected to sport and musical activities as a waste of time and "as privileges of the few at the cost of many" ${ }^{84}$ refusing to grant time off for training and playing - these were in a minority and against the tide. $^{85}$ The passage of time only expanded the officially prescribed institution of police leisure.

\section{THE INVOLVEMENT OF HIGH SOCIETY}

In their attempts to mould "men in whom they could feel the greatest confidence", the police authorities were aided enthusiastically by outside sources. ${ }^{86}$ Apparently, work-sponsored leisure was so persuasive an idea that it elicited support from the higher social and political echelons of the country - as high up, in fact, as the Royal Family, who deemed it important to invest their time and energy in shaping a police force of a certain kind. National and local dignitaries, with their families and friends, honoured recreational events with their presence and attended, and sometimes presided over, celebrations for winning teams. ${ }^{87}$ Well-to-do and privileged members of the community sponsored and even financed

80. Ibid., is July i9ro, p. 333.

81. Police Chronicle, i I August i888, p. 4.

82. Ibid., 4 January I913, p. 6.

83. Police Review, I9 March 1909, p. I44.

84. Royal Commission upon the Duties of the Metropolitan Police, PP, 1908, vol. 5I, p. 178.

85. Police Review, I 2 June I 893, p. 279.

86. Ibid., 30 January I 893 , p. 52.

87. See, e.g., report on the celebrations in honour of the awarding of the Cricket League Cup to the Halifax borough force, attended by the local Chief Constable, Chairman of the Watch Committee, aldermen, councillors, local businessmen, senior police officers, the League officials and the cricket team (Ibid., I6 September I9I0, p. 444). 
balls, dinner dances, sporting occasions, and police performing groups. The Princess of Wales and the Dukes of Richmond and Sutherland were among those who gave police bands their patronage and monetary support. Lord Tredegar lent the Cardiff Constabulary the Cardiff Harlequins Ground for police races in such sports as flat and bicycle handicap, long jumps, hammer throwing, quarter-mile walking, and tugof-war. ${ }^{88}$ Free entertainment was provided for the City of London policemen and their wives in January 1875 because Mr A. Rothschild "made a handsome contribution towards the expenses incurred". ${ }^{9}$ Mayors and other local notables made donations to police recreation clubs and hosted police soirées..$^{\circ}$ The Cricket Cup trophy in Birmingham was a gift from a local businessman. These are just a few examples of the extensive support by the political and economic elite for police recreation during the period under review.

In short, the desire to shape compliant and stable workers was not restricted to the police leadership. It extended to the entire political and economic establishment, some of whom continued to sponsor all manner of cultural activities in society. Yet, their involvement in police entertainment seems to have been particularly conspicuous, extending to members of the royal house. This is not surprising, given the special role played by the police in society, i.e. as protectors of the social status quo. The entrenchment and enhancement of a specific kind of police subculture was therefore important. Police patrons were particularly interested in promoting abstinence of drink among policemen, devoting time and resources to the establishment of police temperance societies, and joining efforts to prompt officers "to sign the pledge" of abstinence..$^{9 \mathrm{I}}$ As the Chairman of the Watch Committee in Hull explained to members of the Hull Police Temperance Society in I 893, neither the monarch nor the highest judge or stipendiary magistrate "was clothed with so much power for prompt and unobserved action as the members of the Police Forces in the various parts of the country". It was of vital importance, therefore, that they not act under the influence of drink..$^{9^{2}}$ To attract officers to join, the police temperance societies provided their members with teas and other social events where respectable recreation, such as singing, recitations, and concerts, were the norm.

Deeply concerned with the deterioration of religious influence in the country, and guided by the example of church groups who used recreation as a means of bringing people back to the faith, Miss Catherine Gurney and other wealthy benefactors founded the International Christian Police

88. Police Chronicle, I9 October I90I, p. 7.

89. Police Guardian, 22 January I875, p. 4.

90. Ibid., 9 March I888, p. 2.

91. Police Review, 30 January I 893 , p. 52.

92. Ibid. 
Association in 1883 with headquarters in London. ${ }^{93}$ Its aim was to spread Christian practice among policemen, a goal its founders meant to accomplish by luring officers away from temptations as well as by easing their discomforts. ${ }^{94}$ All new recruits to the Metropolitan Police were invited to the central office in London, where they were encouraged to become "soldiers of Christ" and make a commitment to abstinence. 95 With the intention of getting "hold of the young ones before they went wrong and got into bad ways", lectures, social evenings, prayer meetings, and Bible classes were offered. ${ }^{96}$ A monthly journal entitled On and Off Duty was founded so that "what appears in its pages may be read when 'off duty', and recollected when on". ${ }^{97}$

The Association provided services that could appeal as well to policemen who were not attracted by the religious message. The Central Police Institute, where the headquarters were located, provided "a hearty welcome" and "a safe and home-like place" to spend the night for new recruits and for any policeman in the metropolitan, city, or provincial forces as well as for policemen from the colonies. ${ }^{98}$ It was furnished with such amenities as a reading and smoking room, a tea and refreshments room, a coffee bar, a meeting and class room, and bedrooms. The reading room contained newspapers and magazines, chess, draughts, writing materials, and a lending library. The Institute had a choir and a band. Soon, branches were set up in different parts of the country and overseas, providing similar services. These branches, too, enjoyed the support of benefactors. The Cardiff Police Institute, for example, was given a house rent-free for its programmes. ${ }^{99}$ This backing, and the Association's support of police causes such as the police seaside home and police orphanages, enabled patrons to instil consensual values in policemen and in the orphans of police officers. At the same time, they enjoyed performances by policemen and the children's choir, as well as drill exhibitions at the Association's social events and meetings. ${ }^{100}$ That top police administrators encouraged these missionary efforts is reflected in their promotion of the organizations involved. Chief Constables facilitated encounters between young recruits and activists so that the latter would have "a grand opportunity of persuading [the recruits] to give their hearts to God as they entered into the dangers and temptations which

93. Bailey, Leisure and Class in Victorian England, pp. 79-82.

94. Police Review, 4 May 1906, p. 207.

95. Ibid., 20 March I 893 , p. I34.

96. Ibid., p. I35.

97. On and Off Duty, I (I883), p. I.

98. Police Chronicle, 28 August I909, p. 2.

99. Police Review is April I9ro, p. I70.

I००. For the various activities of the Association, see its journal, On and Off Duty. 
surrounded them". ${ }^{\text {IOI }}$ In like manner, members of the Police Temperance Societies were less likely to be charged with misconduct than policemen who took no part in these pursuits. ${ }^{102}$ The heads of police and the local elites were only too happy to attend events organized by such bodies as the International Christian Police Association, where they would be entertained and publicly thanked for their presence, support, and efforts.

The participation of civilian dignitaries and local politicians in police recreational activities clearly served both police purposes and their own interests. Although the motives behind their attendance at such events were in part benevolent and charitable, their presence constituted yet another symbol of control over policemen and, by extension, over the population at large. Even at the leisure venues, which provided an arena for physical proximity between different ranks and classes, the elites, whether of the police or of society at large, maintained a careful distance from ordinary police officers. Class lines were clearly demarcated and the officers' subordination was emphasized. The events and ceremonies may have created a semblance of class conciliation, but in practice perpetuated the social gap in the manner of the old paternalism. Moreover, in supporting police leisure, the privileged strata of the population buttressed their status as patrons. Police entertainment venues became meeting points for local politicians, businessmen, and other pillars of the community and their families, giving them an opportunity to enhance their status as patrons of the public good. The occasional presence of members of the hereditary nobility in police entertainments further elevated the standing of these local elites.

The involvement by political and monied patrons in police-related leisure indicates that patronage continued to be an important factor in working-class sports and other entertainments even in the late nineteenth and early twentieth centuries. While the aristocracy and the gentry had reduced their centuries-old support of plebeian culture, particularly animal blood sports and popular fêtes, withdrawing "into their own largely exclusive social world", at the same time they "continued to support a wide range of other sports" and entertainments in which there was extensive working-class involvement. ${ }^{103}$ Police leisure is a case in point, suggesting that such support was either restructured or rechannelled towards institutions and occupational groups of a new kind, like the police. During the second half of the nineteenth century, support of working-class sports and recreation expanded to include bourgeois patrons as well. Although within the confines of their work environment,

103. Neil Tranter, Sport, Economy and Society in Britain 1750-19I4 (Cambridge, I998), pp. 4, 8-9; Metcalf, "Football in the Mining Communities of East Northumberland", pp. 279-280. 
certain working people, notably in the public sector, thus enjoyed broad patronage by the social elite, both locally and nationally. This phenomenon indicates the resilience of traditional paternalist attitudes, albeit adapted to new techniques of social control. It also reflects the Victorian emphasis on the goal of the moral betterment of the lower classes.

\section{OFFICERS' RESPONSE TO POLICE LEISURE}

Police recreation did not benefit all officers equally. They, too, as their superior officers, were not unanimous in their perception of the utility and desirability of the police-sponsored leisure system. Some were impressed by it and others were not. Some welcomed the opportunity to enrich their spare time and others could dispense with it altogether.

Moreover, participation in recreational activities was not always the outcome of choice. The authorities often pressured the men to take part in these activities or into organizing them. Quiet a few officers denounced this incursion into their leisure time, regardless of the enjoyment they may have derived from it. The Police Review received scores of letters expressing "strong and resentful criticisms of police festivities", in which officers took "exception to being drawn, more or less compulsorily, into some of these forms of so-called 'enjoyment' ". ${ }^{104}$ They preferred "to sink their official identity for such purposes, and to share these pleasures with their fellow men in ordinary life, rather than with Policemen, under the peculiar conditions of discipline to which constables are subject". ${ }^{\text {IOS }}$ In the view of some of the men, "enforced pleasure is not pleasure". ${ }^{\circ 06}$ Rather than be "taken to some out-of-the-way place, under rule and authority [...] where they must not leave without leave", they opted to "follow their own inclinations". ${ }^{107}$ Like many other workers, even policemen, who were expected to accede to all police norms, resented the element of control in their after-work hours.

Whereas these officers expressed an explicit desire to be masters of their own free time and choose their own friends, other officers valued the introduction of recreational facilities into the work environment and the camaraderie that went along with it, but found fault with the way the system of leisure operated. A strong undercurrent of discontent existed among the rank-and-file, who felt that the recreational system did not benefit officers equally, and that it was imbued with discriminatory attitudes. The favoured group consisted of officers who excelled principally in sports but also in the performing arts. Pleased by the

104. Police Review, 24 January 1913, p. 43.

105. Ibid.

106. Ibid., I I September I893, p. 436.

I07. Ibid. 
excitement generated by matches, competitions, and the prestige evoked by winning or performing, some senior officers endowed these policemen with special dispensations. Reports cited "special facilities [...] freely given so that the men might have opportunities for practice". ${ }^{108}$ When the time came to prove their skills in public, these officers' duties were arranged with a view to enabling them to participate in the events. They were given time off in order to practice, train, and play, while "the less favoured men" had to pay the price of such privileges and perform "extra duties". ${ }^{109}$ Not surprisingly, many officers found this situation vexing. ${ }^{\text {I }}$ "According to the Chief Constable of the Halifax Borough Police: "There was no force in England that had a cricket team where the difficulty did not arise". ${ }^{\text {II }}$

Resentment was heightened by other manifestations of this syndrome. In some sports clubs, officers who did not excel in competitive games were precluded from regular participation or even membership. This was the case in several cricket clubs where senior officers carefully selected the members who were more likely to contribute to winning the cup. Moreover, matches involving the best players tended to be in privileged locations, such as the seaside, and were attended by top police officials whose presence ensured that these events were followed by entertainments and flattering speeches. ${ }^{\text {II } 2}$ Matches where the players were of lesser ability were not deemed worthy of the presence of important personages and took place in "some out-of-the-way place, far from a station, where they have to tramp a hot dusty road for about two miles, to some meadow or park". ${ }^{113}$ Although these matches, too, were followed by dinners, the catering was "very imperfect", there was no "drinking of health", and, therefore, no "flattering palaver".

To be a policeman with the potential of attaining impressive athletic results also implied remunerative advantages. Members of the football team in the $\mathrm{X}$ division of the Metropolitan Police were "provided with all their accoutrements" and were "taken to all 'away' matches in Vanguard omnibuses, the club funds defraying the necessary expenses". ${ }^{14} 4$ Ordinary policemen perceived a hidden agenda in the special relations between the supervisory officers and the players. For example, accusations were made that the men played football in order to "furnish amusement for the

I08. Ibid., 30 April 1909, p. 2 I 5.

I09. Ibid., 23 September I910, p. 453. In defence of this practice, the Commissioner of the Metropolitan Police, Edward Henry, maintained that only some 54 officers out of 6,000 were given time off to play cricket and football and to organize the fête at the Crystal Palace (Select Committee on the Police Forces (Weekly Rest-Day), PP, I908, vol. 9, p. 708).

I I0. Police Review, 8 February I895, p. 63; ibid., 30 November I900, p. 567.

I I I. Ibid., i6 September I910, p. 444.

I I 2. Ibid., 4 September I 893, p. 423.

I 13 . I bid.

II4. Ibid., 30 April I909, p. 2 I 5. 
'Caps" and "get into their good books". ${ }^{\text {Is }}$ In turn, their chances of promotion were "immeasurably improved". ${ }^{116}$

More broadly, workers who had a gift for sports had an edge on their workmates during the late nineteenth century. Their employers tended to accord them special treatment, even as amateurs. This was indeed in evidence within the police, where a distinction was made between sports enthusiasts who garnered fame and prestige for the force and those who played for pleasure only. Contrary to the aim of the police policy makers, this bias in favour of skilled performers, which drew considerable criticism from the rank-and-file, was divisive and disruptive of the desired solidarity. Some policemen reckoned that complimentary speeches at sporting events which, for example, lauded all good cricketers as being good policemen actually caused "an incalculable amount of harm", since the players conceived of themselves as "the only true apostles of the Force". ${ }^{17}$ The result was that "harmony is destroyed, and frigidity, friction, and dissatisfaction takes its place".

Disapproval of the leisure system was rife because, additionally, many officers recognized that it reinforced the hierarchical structure and emphasized the division between constables and supervisory officers. Ex-inspector John Syme complained in I 910 that the nominated officers at the peak of the police pyramid refrained from taking part in police leisure and played the role of patrons only, while the middle ranks, who did mix with the lower ranks, at times abused the system of leisure by mishandling funds for their own benefit. ${ }^{\text {II } 8}$ Syme further alleged that while the lower ranks had to buy tickets for police concerts and other events, the superior officers took free tickets for themselves and their friends, occupied the best seats, and were "freely regaled with refreshments at the expense of the charitable". Many concerts, he observed, became "nothing else but drunken orgies behind the scenes". While the superintendents and chief inspectors helped themselves to surplus stores of drink and cigars and drew freely upon athletic club funds for the entertainment of their friends, "the poorly-paid Constable buys his own ticket, beer and tobacco". Syme also claimed that the money collected from the men for stocking the library was spent on pictures and books for the superior officers' rooms. Exinspector Syme may have been particularly bitter and censorious of the superior ranks because he was expelled from the Metropolitan Police for insubordination, but his basic arguments were echoed by other officers. ${ }^{19}$

Another aspect that angered many officers was orders to sell tickets and

I I s. Ibid., 23 November 1894, p. 556.

I 16. Ibid., 6 November I893, p. 53 I.

I17. Ibid., 4 September I893, p. 423 .

I1 8. Ibid., 23 September 1910, p. 453.

I 19. E.g., Penny Illustrated Paper, I October I9 IO, p. 429; Police Review, 24 January I9I 3, p. 43. 
collect money from local tradesmen and ratepayers for the social events organized by the police. It was not uncommon for policemen to sell tickets to and solicit donations from publicans and brewery companies, who, as "the most formidable vested interest in popular recreation", unsurprisingly turned out to be "the greatest donors". ${ }^{\text {I20 }}$ Some complained that if they were not successful in canvassing, they had to suffer disagreeable consequences. ${ }^{\text {I2I }}$ Not infrequently, officers were ordered to sell tickets to events reserved for the higher ranks and their friends, from which they themselves were excluded. Sometimes, the bulk of the money collected during sporting events and advertised as a donation to charitable causes, such as the police orphanages or the police hospital, merely covered expenses for the event. Thus, with all the advantages made available to police officers, the world of police leisure also mirrored the exploitative relations between the ranks in police work. Those who enjoyed privileged conditions at work maintained their advantageous positions during leisure; control was exerted both during and after work hours.

Nevertheless, there is ample evidence of the popularity of the recreational facilities offered to members of the police forces at their place of work. Despite the objections noted above, the impression emanating from police records is of extensive use of the leisure facilities provided by the police. An article in the Police Review in I894, entitled "How the Police Amuse Themselves", asserted conclusively that "very few of us [...] have to go outside for our pleasures". ${ }^{\text {I22 }}$ After a hard day's work, officers relaxed in the recreation room, the reading room, or the library, or practised with their colleagues at the police sports clubs. ${ }^{23}$ Indeed, police recreation rooms were often filled to capacity. Moreover, many officers took this recreation quite seriously. Outdoor sports proved especially challenging, as in working-class environments in England generally. Members of the City of London Police's tug-of-war team, for example, abstained "from all pleasures", and kept "in hard training for over six months" before the race. ${ }^{\mathrm{I}} 4$ Officers flocked to watch games and matches and celebrated the success of their team jubilantly. ${ }^{\mathrm{I} 25}$ As a whole, the recreational infrastructure was built for them with little effort or investment on their part, and some facilities were provided free of

I20. Bailey, Leisure and Class in Victorian England, p. 40; Police Review, 29 November I 895, p. 568; ibid., 6 December I 895, p. 579. Cf. Metcalf, "Football in the Mining Communities of East Northumberland", p. 282.

I2 I. Police Review, 6 December i895, p. 579.

I22. Ibid., 25 May i 894, p. 244.

I23. "The Policeman's Diary", All the Year Round, 5 January I889, p. 8.

I24. Police Review, 9 February 1906, p. 71.

I 25. See, e.g., Police Service Advertiser, 30 August I872, p. 3; Police Review, I6 September I9 I0, p. 444 . 
charge. ${ }^{126}$ The range of police amusements was so wide that pursuits which in the past had been the preserve of a select few in society, and were still not widely accessible to the policemen's social class, now became available for the officers' enjoyment. While policemen were barred from such areas of popular recreation as drinking and gambling, most of the activities encouraged by the police gradually developed into standard pastimes everywhere.

Work-related leisure was satisfying also because it allowed policemen to become public figures and win popular acclaim. Officers appeared in concerts, readings, and humorous performances, played in games, and participated in a host of sporting competitions in which they sometimes won prizes both as individuals and as part of a team. They appeared publicly in a variety of venues ranging from police stations and institutions to public halls, parks, and working-class clubs. Displaying bodily vigour, endurance, prowess, and team spirit, they sometimes made a name for themselves and thereby enhanced their self-image in the police and in the community at large. Some policemen managed to sign on for professional teams. ${ }^{127}$ Reports of the matches appeared both in the Police Review and in the Police Chronicle, which mentioned the names of the main players and of those who won medals and prizes. Police events attracted a crosssection of society, from members of the Royal Family to casual visitors at open-air concerts. Indeed, many of the events became community occasions that constituted an important part of the local entertainment scene. One example was the appearance by the Metropolitan Police Minstrels, who attained national acclaim and were considered "one of the finest companies of the kind in the United Kingdom". ${ }^{128}$ Tickets for their performances sold well, and the demand for seats often exceeded the supply. Often, performers or players in a team were publicly complimented and praised. Members of a cricket team were said to be "hard at work and were also hard at play". ${ }^{29}$ Occasionally, performers in police entertainment groups, such as members of a band, could earn money from their activities which they could keep for their own use.

Although officers were induced to amuse themselves within the framework laid out for them by their superiors, they were not merely passive recipients of the authorities' initiatives. They had personal preferences and interests, and these usually determined their choice of recreation. Some recreational facilities and pastimes were more popular

I 26. That financial backing from above was essential for the development of working-class leisure is clear from the example of the fluctuating fortunes of football clubs in the mining communities; see Metcalf, "Football in the Mining Communities of East Northumberland", pp. 274-278.

127. Police Review, 30 April I909, p. 2 I 5.

I28. Ibid., I 3 February I 893, p. 73.

I29. Ibid., I6 September I910, p. 444. 
than others. Billiards proved the favourite game in the recreation rooms. ${ }^{130}$ Football and cricket were the preferred outdoor activities. Those who were keen on respectable and temperate living approved of the leisure choices introduced by the authorities. Some officers formed their own performing groups and took the lead both in enhancing their leisure activities and in administering them. The organization of certain music bands was "entirely voluntary", untouched by the police elite. ${ }^{\mathrm{I} 3 \mathrm{I}}$

Moreover, officers could have an effect on decision making, as recreational facilities were occasionally built in response to their requests. The new gymnasium that opened in May I 899 for the benefit of the City of London Police, "fitted with every modern arrangement", was one such case. ${ }^{\mathrm{I} 2}$ The entrenchment of football inside the force in preference to rugby was the result of the officers' choice, even though the opinion of the top ranks was that "the latter would have been of greater advantage to Policemen, who often had to 'tackle' and to get out of a 'scrum' when 'tackled' by roughs". ${ }^{133}$ As a consequence, the diversity of leisure opportunities in the police, depended to some extent on officers' pressure. In fact, police leisure culture could not have been as dynamic and sustained as it was without employee initiative. ${ }^{\mathrm{I}} 34$ Ultimately, by participating extensively in employer-based recreations while developing activities consonant with their own inclinations, ${ }^{\mathrm{I} 35}$ policemen served as cultural transmitters, diffusing popular and respectable pleasures in English society at large.

\section{CONCLUSION}

Only a minority of employers during the late nineteenth and early twentieth centuries took it upon themselves to correct their workers' behaviour after work. Even fewer acted upon the belief "in the socially stabilising powers of bourgeois forms of sport" or other types of leisure activities. ${ }^{136}$ The majority relied on agents of the state, such as the police, or on religious and other organizations to imbue the working classes with

\footnotetext{
I30. Ibid., 25 May i 894, p. 244.

I3 I. Report of the Commissioner of the Metropolitan Police to the House of Commons for the year I 870 , PP, I 871 , vol. 28 , p. 595 .

I32. Police Review, I9 May I899, p. 232.

I33. Ibid., 6 July 1906, p. 316.

I34. This was true for other workplaces as well. Unlike the police authorities, some employers, including several of the railway companies, reduced their after-work intervention during the closing decades of the nineteenth century; see e.g. Allan Redfern, "Crewe: Leisure in a Railway Town”, in John K. Walton and James Walvin (eds), Leisure in Britain (Manchester, 1983), pp. I I7-I 35; Bailey, Leisure and Class in Victorian England, pp. I I2-I I3. In quite a few of these cases, the workers themselves replaced their employers' endeavours.

I35. See letters in the Police Review, 6 July 1900, p. 320.

I36. Tranter, Sport, Economy and Society in Britain 1750-1914, pp. 45-46.
} 
correct habits. Generalizations about those employers who did provide their employees with recreation at the place of work are difficult to construct, as both rural and industrial, large and small, and private and public employers may be included in this group. ${ }^{137}$ The type and scale of recreations introduced by each employer varied greatly and changed over time. Broadly, however, large-scale public organizations such as the post office, prison service, railway companies, and police were conspicuous in developing elaborate systems of leisure regularly enjoyed by large sections of the labour force. ${ }^{138}$ They, too, differed in the activities they provided, but what they shared in common was that their efforts were part and parcel of a wider strategy to monitor and influence the worker's total environment. Typically, these work organizations were critically dependent on a disciplined, reliable, and stable workforce to provide satisfactory services for the community, and had the resources and bureaucracy to administer a leisure-time programme.

The police, therefore, were far from unique in maintaining the centuriesold tradition of intermingling work and leisure. Arguably, however, they were exceptionally active in this sphere. Police policy makers, deeply concerned with the activities and whereabouts of the men outside their disciplined work environment, and aiming at building up a workforce that was committed, enduring, and easily moulded, firmly subscribed to the corrective approach and developed a series of internal mechanisms to superintend the leisure time of their employees. Conceivably, the police leadership was more apprehensive about the quality of the labour force than other public employers and keener to acquire a good public image through the many recreational events open to the population at large. This desire and the special role assigned to the police by the country's establishment explains the considerable patronage and backing extended to police leisure by the social and economic elite. In addition to their responsibility for maintaining order and protecting the public against malpractice and violations of the law, policemen also guarded the interests of the local and the national elites. It was vital for these elites, therefore, to do all in their power to vindicate the existence and the practices of the police, especially since their own standing in the community was thereby strengthened. For all these reasons, as well as the greater need for

I 37. Robert D. Storch, "The Problem of Working-Class Leisure: Some Roots of Middle-Class Moral Reform in the Industrial North: I 825-50", in A.P. Donajgrodzki (ed.), Social Control in Nineteenth Century Britain (London, 1977), p. I48; Howard Newby, "Paternalism and Capitalism", in Richard Scase, Industrial Society: Class, Cleavage and Control (London, 1977), p. 68.

I38. For the provision of leisure by the railway companies, see Robert Fitzgerald, British Labour Management and Industrial Welfare I846-1939 (London, 1988), p. 35; Redfern, "Crewe: Leisure in a Railway Town", pp. I I9-I20. 
employers to heed their workers' demands by the latter part of the century, police recreation became prominent in the social landscape.

Given that the efforts made by the police authorities had a pragmatic purpose in mind - to mould and shape a certain type of employee, strong, stable, obedient, respectable, cooperative, and on good terms with his colleagues and with the community he policed - the question arises as to whether these efforts fulfilled their aims. Were the policy makers correct in their assessment of the impact of police leisure?

Ultimately, the answer to this question is unclear. Physical exercise through sports may have contributed to a healthier and physically stronger police force, but the effect of work-related leisure on the behaviour of the officers is more conjectural. Evidence of police performance in the late nineteenth and early twentieth centuries indicates that the labour force was becoming progressively more stable and acceptable to the public, and showed greater conformity in working habits. ${ }^{139}$ Since this was happening precisely during a period of greater investment by police management in recreational facilities, the policy of leisure may appear to have had the desired consequences. However, at the very same time, other beneficial policies were introduced, notably in the field of welfare. ${ }^{\mathrm{I}}{ }^{\circ}$ The cumulative effects of all these changes together could explain the greater commitment and solidarity felt by the men. In turn, this solidarity may account for greater militancy shown by police officers and a heightened determination to fight for the amelioration of their employment conditions during the very same period. ${ }^{\text {III }}$ Policemen may have become more cooperative in carrying out duties, and more identified with their occupation, but they did not necessarily become more deferential or more content.

Moreover, there is enough evidence to show that many officers, as the working population they policed, continued to enjoy traditional workingclass pastimes deemed unruly and debasing by the respectable public. The police administration found it difficult "to supplant the public house in the affections and habits" of policemen, a reflection of the norms of working men generally. ${ }^{\mathrm{I}}{ }^{2}$ Police officers were occasionally caught visiting pubs during and after work hours, gambling, and consorting with prostitutes activities that were at variance with regulations. ${ }^{\mathrm{I} 3}$ Thus, officer participation in police leisure did not necessarily lead to the assimilation of the values believed to be implicit in such recreation.

Evidence also indicates that the men were aware of the control element

I39. Shpayer-Makov, "Making of a Police Labour Force”, p. I09.

I40. Ibid., pp. I I2-II4.

I4I. Gerald W. Reynolds and Anthony Judge, The Night the Police Went on Strike (London, I968), pp. 202-232.

142. Bailey, Leisure and Class in Victorian England, p. I78.

I43. See, e.g., minutes of the Royal Commission upon the Duties of the Metropolitan Police, PP, I908, vols 50-5 I; Brian Harrison, Drink and the Victorians (Keele, I994), p. 358. 
in the recreations established for them, and quite a few openly expressed their resentment of this strategy. Moreover, policemen found ways of resisting organized leisure and using it for their own benefit, for example, going to police Bible classes with the idea that it would help their promotion, while they had in their pockets "a pack of cards, a betting-

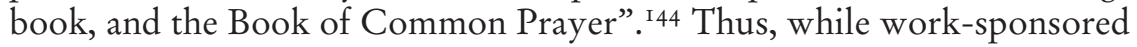
leisure served as a source of enjoyment, it was also a locus of class conflict and tension. Indeed, an examination of police history confirms Peter Bailey's conclusions that control through such leisure "was never complete", that workers invented "counter strategies of resistance", and employed "selective adaptation", and that leisure is an "instrument through which people make their own history". ${ }^{\text {I45 }}$ Such was the situation even within the regimented confines of the police setting. As Hugh Cunningham, another seminal historian of leisure, has argued: "The sponsorship and patronage of the rich certainly did not imply a submission to their control and values". ${ }^{4} 46$

Yet, while off-duty culture underscored class, rank, and status differences, it simultaneously bonded policemen and heightened their collective consciousness and identity. Socializing, engaging in sport together, winning, and even competing against each other acted as a unifying force. Policemen cherished their independence and resented the kind of leisure which was discriminatory, but they also put on a good show and had a good time, and while doing so they entrenched police solidarity and forged a distinct occupational culture.

Whatever the degree of involvement of the public-sector organizations in the after-work hours of their employees, together they played a significant role in relinking work and leisure in the changing world of Victorian and Edwardian England. Traditional attitudes and practices persisted, albeit by undergoing adaptation. Work and leisure were still interwoven but in new forms, and for different purposes, in line with the demands of contemporary employment structures and work concepts. The relatively new public-sector employers, faced with the need to construct innovative work organizations, set in motion new workplace cultures. Employing hundreds of thousands of workers, they left an indelible mark on the consolidation of working-class culture in Victorian and Edwardian England.

144. Police Review, 6 December 1895, p. 579.

145. Bailey, Leisure and Class in Victorian England, pp. 9-I I.

146. Hugh Cunningham, Leisure in the Industrial Revolution (London, 1980), p. I28. 